\title{
БИОЛОГИЧЕСКИ АКТИВНЫЕ ВЕЩЕСТВА CORYLUS AVELLANA L., ПРОИЗРАСТАЮЩЕЙ В АЗЕРБАЙДЖАНЕ
}

\author{
() И.С. Мовсумов, Д.Ю. Юсифова, Э.А. Гараев* \\ Азербайджанский медицинский университет, ул. Бакиханова, 23, Баку, $A Z$ \\ 1022 (Азербайджан), e-mail: eldargar@mail.ru
}

\begin{abstract}
С целью поиска новых источников получения биологически активных веществ впервые изучены химические компоненты сырья - листьев C. avellana L. (лещина обыкновенная) сем. Corylaceae Mirb (лещинные) из флоры Азербайджана. Из листьев этого растения были выделены и идентифицированы тритерпеновый спирт - бетулин, флавоноиды мирицетин (3,5,7,3',4',5'-гексаоксифлавон), кверцетин (3,5,7,3',4'-пентаоксифлавон), кемпферол (3,5,7,4'-тетраоксифлавон), кверцитрин (кверцетин-3-O- $\alpha$-L-рамнозид), афзелин (кемпферол-3-O- $\alpha$-L-рамнозид) .

Ключевые слова: лещина обыкновенная, бетулин, мирицетин, кверцетин, кемпферол, кверцитрин, афзелин.
\end{abstract}

Корни, кора, листья, плоды C. avellana L. применяются в народной медицине при различных заболеваниях. Как, например, отвар корней при малярии. Настой коры и листьев применяют при варикозных язвах, капиллярных геморрагиях. Настой листьев применяют для лечения кишечных заболеваний, анемии, авитаминозах, рахите. Отвар листьев применяют при гипертрофии предстательной железы. Получаемая сухой перегонкой древесины жидкость «Л-2 лесовая» используется при различных заболеваниях кожи при экземе, нейродермите, стрептодермии, псориазе, эпидермофитии [1].

Из 20 видов Corylus L., растущих главным образом в Северном полушарии, на Кавказе - шесть, в Азербайджане - три вида [2].

Несмотря на вышеизложенные, в настоящее время химический состав и фармакологические свойства этих видов флоры Азербайджана не изучены $[1,2]$.

Для изучения химического состава использовали сырье (листья) C. avellana L., заготовленное нами в окрестностях города Губа в конце июня 2011 г. и Шеки в начале октября того же года.

1,5 кг воздушно-сухих листьев C. avellana L. экстрагировали 95\%-м этанолом трижды, в соотношении $1: 8$. Экстракты объединяли, упаривали в вакууме до 250-300 мл, прибавляли 300 мл воды и упаривали до водного остатка. Водный раствор последовательно обрабатывали хлороформом, смесью этилацетат гексан и этилацетатом. Из хлороформного извлечения после очистки с окисью алюминия (II степень активности) получили вещество 1.

Вещество 1. Состав $\mathrm{C}_{30} \mathrm{H}_{50} \mathrm{O}$, т. пл. $249-251{ }^{\circ} \mathrm{C}$ (этанол). Реакция Либермана-Бурхарда является положительной. На ТСХ с 25\%-м спиртовым раствором фосфорновольфрамовой кислоты, с последующим нагреванием при 100-105 ${ }^{\circ} \mathrm{C}$ обнаруживается в виде розового пятна. ИК-спектр: 3400 (-ОН); 1643, 885 см $^{-1}$ $\left(>\mathrm{C}=\mathrm{CH}_{2}\right)$. Таким образом, вещество 1 идентифицировали как тритерпеновый спирт - бетулин [3].

Из извлечения смесью этилацетат - гексан после упаривания и препаративной бумажной хроматографией выделили вещество 2 и 3.

Вещество 2. Состав $\mathrm{C}_{15} \mathrm{H}_{10} \mathrm{O}_{7}$, т. пл. $310-312{ }^{\circ} \mathrm{C}$ (этанол), т. пл. ацетата $198-200{ }^{\circ} \mathrm{C}$. УФ-спектры $\left(\lambda_{\max }\right.$, метанол, $\mathrm{nm}): 375,256$. При цианидиновой пробе по Брианту образуется малиновое окрашивание, указывающее на

Мовсумов Исрафиль Солтан огль - профессор, доктор фармацевтических наук

Юсифова Джсамиля Юсиф гызы - доцент, кандидат фармацевтических наук

Гараев Эльдар Абдулла огль - доцент, кандидат фармацевтических наук, e-mail: eldargar@mail.ru флавоноловую природу [4]. В УФ-свете на хроматограмме имеет желтую флюоресценцию. Продуктами щелочного распада вещества 2 являются флороглюцин и протокатеховая кислота. Вещество 2 идентифицировали как кверцетин (3,5,7,3',4'-пентаоксифлавон) [5].

\footnotetext{
* Автор, с которым следует вести переписку.
} 
Вещество 3. Состав $\mathrm{C}_{15} \mathrm{H}_{10} \mathrm{O}_{8}$, т. пл. $355-357{ }^{\circ} \mathrm{C}$ (этанол). Т. пл. ацетата $218-220{ }^{\circ} \mathrm{C}$. В УФ-свете вещество 3 на хроматограмме имеет желтую флюоресценцию. УФ-спектры ( $\lambda_{\max }$, метанол, nm): 379, 340 пл, 254. Вещество 3 при цианидиновой реакции по Брианту образует малиновое окрашивание, указывающее на флавоноловую агликоновую природу. ИК-спектры $\left(\mathrm{KBr}, \lambda_{\max }\right.$, метанол, $\left.\mathrm{cm}^{-1}\right): 3380-3300,1660,1565$, 1516. Вещество 3 идентифицировали как мирицетин $\left(3,5,7,3^{\prime}, 4^{\prime}, 5^{\prime}\right.$-гексаоксифлавон) $[4,6]$.

Чтобы предварительно установить природу флавоноидных гликозидов, часть этилацетатного извлечения после упаривания растворителя подвергали кислотному гидролизу $\left(4 \% \mathrm{H}_{2} \mathrm{SO}_{4}, 4\right.$ ч). При этом наряду с кверцетином и мирицетином получили вещество 4.

Вещество 4. Состав $\mathrm{C}_{15} \mathrm{H}_{10} \mathrm{O}_{6}$, т. пл. 277-279 ${ }^{\circ} \mathrm{C}$. Кристаллы лимонно-желтого цвета, растворим в ацетоне, спиртах, нерастворим в воде и хлороформе. УФ-спектры ( $\lambda_{\text {мах }}$ метанол, $\mathrm{nm}$ ): 253 пл., 266, 294, 322 пл., 367. В ИК спектре обнаруживаются полосы поглощения флавоноидов: 3400-3200, $1665 \mathrm{~cm}^{-1}$. При щелочном гидролизе образуется флороглюцин и $n$-оксибензойная кислота. Т. пл. ацетата $182-185^{\circ} \mathrm{C}$. Вещество 4 идентифицировали как кемпферол (3,5,7,4'-тетраоксифлавон) [5].

Из оставшей части этилацетатного извлечения после упаривания растворителя препаративной хроматографией на бумаге получили вещество 5 и 6.

Вещество 5. Состав $\mathrm{C}_{21} \mathrm{H}_{20} \mathrm{O}_{10}, 2 \mathrm{H}_{2} \mathrm{O}$, т. пл. $170-172{ }^{\circ} \mathrm{C},[\alpha]_{\mathrm{D}}{ }^{20}-190^{\circ}$ (с 0,6 ; метанол). УФ-спектры $\left(\lambda_{\max }\right.$, метанол, nm): 348,267. $\mathrm{R}_{\mathrm{f}} 0,79$ (здесь и далее: на бумаге марки Filtrak FN 17; в системе: БУВ, $4: 1: 5$ ). При количественном кислотном гидролизе получили в качестве агликона кемпферол $(64,1 \%)$, а в качестве углеводного остатка обнаружили L-рамнозу. Вещество 5 в УФ-свете на хроматограмме имеет темную, агликон - желтую окраску. Вещество 5 идентифицировали с афзелином (кемпферол-3-O- $\alpha$-L-рамнозид) [7].

Вещество 6. Состав $\mathrm{C}_{21} \mathrm{H}_{20} \mathrm{O}_{11}$, т. пл. $173-175^{\circ} \mathrm{C}$, $[\alpha]_{\mathrm{D}}{ }^{20}-160^{\circ}$ (с 0,$1 ;$ метанол). УФ-спектры ( $\lambda_{\text {мах }}$, этанол, $\mathrm{nm}): 355,257 . \mathrm{R}_{\mathrm{f}} 0,71$. Вещество 6 в УФ-свете на хроматограмме имеет темную окраску. При кислотном гидролизе $\left(3 \% \mathrm{H}_{2} \mathrm{SO}_{4}, 34\right)$ в качестве агликона обнаружили кверцетин $(63,8 \%)$, а в качестве углеводного остатка L-рамнозу. Вещество 6 идентифицировали как кверцитрин (кверцетин-3-O- $\alpha$-L-рамнозид) [8, 9].

Качественные составы химических компонентов сырья (листьев) C. avellana L., заготовленные в конце июня и в начале октября 2011 г., одинаковы.

\section{Вbыводы}

1. Из сырья (листья) C. avellana L., произрастающей в Азербайджане, впервые были получены и идентифицированы тритерпеновый спирт: бетулин; свободные флавоноловые агликоны: мирицетин, кверцетин; после гидролиза суммы флавоноидов: кемпферол, кверцетин, мирицетин; флавоноловые гликозиды: афзелин и кверцитрин.

2. Думаем, что полученные данные могут быть стимулом для углубленных фармакологических исследований отдельных флавоноидов или суммы флавоноидов C.avellana L. для получения лекарственных препаратов.

\section{Список литературы}

1. Растительные ресурсы СССР. Цветковые растения, их химический состав, использование. Семейства Мagnoliaceae - Limoniaceae. Ленинград, 1985. 460 c.

2. Флора Азербайджана. Баку, 1952. Т. ІІІ. 406 с.

3. Атлас лекарственных растений СССР. М., 1962. С. 84.

4. Чумбалов Т.К., Фадаева О.В. Флавоноиды Artemisia transilensis // Химия природных соединений. 1969. №5. С. 439.

5. Мовсумов И.С., Гараев Э.А., Юсифова Д.Ю. Химические компоненты цветков Flipendula ulmaria и F. vulgaris из флоры Азербайджана // Химия растительного сырья. 2011. №3. С. 159-162.

6. Мовсумов И.С., Гараев Э.А. Компонентный состав и биологическая активность рода Limonium (Limoniaceae) // Растительные ресурсы. 2012. Т. 48, вып. 2. С. 288-292.

7. Старовойтова В.И., Запесочная Г.Г. Афзелин из Aflatunia ulmifolia // Химия природных соединений. 1980. №1. С. 125.

8. Мовсумов И.С., Юсифова Д.Ю., Гараев Э.А. Флавоноиды Rumex tuberosus L., произрастающего в Азербайджане // Новые достижения в химии и химической технологии растительного сырья: материалы V Всероссийской конференции с международным участием. Барнаул, 2012. С. 265-266.

9. Кисличенко В.С., Новосел Е.Н. Флавоноиды листьев Pyrus communis, Malus Sylvestris, M. domestica // Химия природных соединений. 2007. №6. С. 584-585. 
Movsumov I.S., Iusifova D.Iu., Garaev E.A. BIOLOGICALLY ACTIVE SUBSTANCES CORYLUS AVELLANA L., GROWING IN AZERBAIJAN

Azerbaijan Medical University, Bakikhanova st., 23, Baku, AZ 1022 (Azerbaijan), e-mail: eldargar@mail.ru

For the first time it were received and identified from the raw materials (leaves) of Corylus avellana L., growing in Azerbaijan, triterpenic alcohol: betulin; free flavonolic aglycons: miricetin, quercetin; after hydrolysis of flavonoids sum: kempferol, quercetin, miricetin; flavonolic glycosides: afzelin and quercitrin.

Keywords: Corylus avellana L., betulin, miricetin, quercetin, kempferol, quercitrin, afzelin.

\section{References}

1. Rastitel'nye resursy SSSR. Tsvetkovye rasteniia, ikh khimicheskii sostav, ispol'zovanie. Semeistva Magno-liaceae Limoniaceae. [Plant Resources of the USSR. Flowering plants, their chemical composition and utilization. Family Magno-liaceae - Limoniaceae]. Leningrad, 1985, 460 p. (in Russ.).

2. Flora Azerbaidzhana. [Flora of Azerbaijan]. Baku, 1952, vol. III, 406 p. (in Russ.).

3. Atlas lekarstvennykh rastenii SSSR. [Atlas of medicinal plants of the USSR.]. Moscow, 1962, p. 84. (in Russ.).

4. Chumbalov T.K., Fadaeva O.V. Khimiia prirodnykh soedinenii, 1969, no. 5, p. 439. (in Russ.).

5. Movsumov I.S., Garaev E.A., Iusifova D.Iu. Khimiia rastitel'nogo syr'ia, 2011, no. 3, pp. 159-162. (in Russ.).

6. Movsumov I.S., Garaev E.A. Rastitel'nye resursy, 2012, vol. 48, no. 2, pp. 288-292. (in Russ.).

7. Starovoitova V.I., Zapesochnaia G.G. Khimiia prirodnykh soedinenii, 1980, no. 1, p. 125. (in Russ.).

8. Movsumov I.S., Iusifova D.Iu, Garaev E.A. Novye dostizheniia v khimii i khimicheskoi tekhnologii rastitel'nogo syr'ia: materialy $V$ Vserossiiskoi konferentsii s mezhdunarodnym uchastiem. [New advances in chemistry and chemical engineering plant materials: the V All-Russian conference with international participation]. Barnaul. 2012, pp. 265-266. (in Russ.).

9. Kislichenko V.S., Novosel E.N. Khimiia prirodnykh soedinenii, 2007, no. 6, pp. 584-585. (in Russ.).

Received December 26, 2012

Revised May 10, 2013

\footnotetext{
* Corresponding author.
} 
